\title{
The future challenges for "clean coal technologies": joining efficiency increase and pollutant emission control
}

\author{
Alessandro Franco*, Ana R. Diaz \\ Dipartimento d'Energetica “L. Poggi”, \\ Università di Pisa \\ Via Diotisalvi 2, 56126 PISA - ITALY \\ phone: +39-050-2217154 fax: +39-050-2217150 \\ e-mail: alessandro.franco@ing.unipi.it
}

\begin{abstract}
Coal offers an abundant widely spread fossil energy resource. It is available at a quite stable price from many international suppliers and it will continue to play a significant role in new generating capacity, if security and diversity of supply remain fundamental. In this paper we point out the state of the art in the field of "Clean Coal Technologies" evidencing the perspectives of improvement and the critical elements. Both the emission control of $\mathrm{NO}_{\mathrm{x}}, \mathrm{SO}_{\mathrm{x}}$ and Particle Matter and the advanced coal conversion pathways like USC, PFBC and IGCC are reviewed and analysed. At the end some elements concerning the perspectives of $\mathrm{CO}_{2}$ emission control strategies are outlined.
\end{abstract}

Keywords: Coal, Energy production, Pollutant control, Advanced Technologies, IGCC.

* Corresponding author

Alessandro Franco

University of Pisa

Dipartimento di Energetica "L. Poggi"

Via Diotisalvi, 2 - 56126 PISA - ITALY

Phone +39-050-2217154 Fax: +39-050-2217150

e-mail: alessandro.franco@ing.unipi.it 
Symbols, acronims and abbreviations

\begin{tabular}{|c|c|}
\hline ASU & Air Separation Unit \\
\hline $\mathrm{CC}$ & Carbon Content \\
\hline $\mathrm{CE}$ & Combustion Efficiency \\
\hline $\mathrm{CR}$ & Conversion Rate \\
\hline $\mathrm{CCT}$ & Clean Coal Technologies \\
\hline $\mathrm{CFBC}$ & Circulating Fluidized Bed Combustion \\
\hline DFGD & Dry Flue Gas Desolforator \\
\hline $\mathrm{EF}_{\mathrm{C}}$ & Emission Factor of coal \\
\hline EFCC & Externally Fired Combined Cycle \\
\hline el & electrical \\
\hline FBC & Fluidized Bed Combustion \\
\hline FGD & Flue Gas Desolforator \\
\hline GHG & Greenhouse Gas \\
\hline HP & High Pressure \\
\hline HV & Heating Value \\
\hline IGCC & Integrated Gasification Combined Cycle \\
\hline IP & Intermediate Pressure \\
\hline LNB & Low $\mathrm{NO}_{\mathrm{x}}$ Burners \\
\hline LP & Low Pressure \\
\hline NGCC & Natural Gas Combined Cycle \\
\hline OFA & Overfire Air \\
\hline PCC & Pulverized Coal Combustion \\
\hline P-CFBC & Pressurized Circulating Fluidized Bed Combustion \\
\hline PF & Pulverised Fuel \\
\hline PFBC & Pressurized Fluidized Bed Combustion \\
\hline PM & Particle Matter \\
\hline SCPF & Super Critical Pulverized Fire \\
\hline SCR & Selective Catalytic Reduction \\
\hline SNCR & Selective Non-Catalytic Reduction \\
\hline th & thermal \\
\hline USC & Ultra Super Critical \\
\hline$\eta$ & efficiency \\
\hline
\end{tabular}




\section{INTRODUCTION}

Coal represents at the present about $70 \%$ of the world's proven fossil fuel resources. Moreover, coal is also the more delocalized resource and it has the lower cost among the different fossil fuels. Thus coal is likely to remain one of the main sources of primary energy for a long time, playing a strategic role in the medium- long- term energy production systems. [1-3].

Electric power from coal has been predominantly generated in pulverized coal-fired power plants. Due to thermodynamic (the use of water) and metallurgic constraints, the efficiency of such plants is rather low. Modern pulverized coal-fired power plants achieve efficiency of about 38-40\% (based on the Lower Heating Value of the fuel) operating at 250-300 bar and at maximum temperature of $550-570{ }^{\circ} \mathrm{C}$. But they are characterized by quite high pollutant emissions especially carbon dioxide (about $800 \mathrm{~g}$ for each $\mathrm{kWh}$ of electric energy produced).

The growing energy demand of the developing countries together with the need of a significant reduction in greenhouse gases (GHG) emissions are the challenging tasks of future energy policies [4]. The perspectives of coal as energy source are based on the success into the energy market of "clean coal technologies" (CCT), where good thermodynamic performances of the power plant are joined with a control of pollutant emissions (mainly $\mathrm{CO}_{2}$ emissions). The most promising are the Ultra Super Critical (USC), the Integrated Coal Gasification Combined Cycle (IGCC) and the Externally-Fired Combined Cycle (EFCC) power plants. [2-4]. The development of CCT is an objective not easy to be performed for different motivations. On the one hand coal is not a uniform source due to its extremely variable composition; this made difficult to reach a standardization of advanced technologies that can be very sensitive to the fuel used. On the other hand coal combustion produces structurally more pollutants that the other fossil fuel since it contains mainly carbon as reactive component (producing $\left.\mathrm{CO}_{2}\right)$ and sulphur $\left(\mathrm{SO}_{\mathrm{x}}\right.$ is the resulting product) but very little hydrogen (turning into $\mathrm{H}_{2} \mathrm{O}$ ). From the aforesaid considerations, the aim of the work is to analyze the perspectives of the particular field of clean coal technologies starting from an analysis of the state of the art. The paper will focus on the emerging suite of technology options and on studies to evaluate their potential to contribute to the nation's energy mix. In addition the current research and development in the "clean coal field" is discussed.

\section{THE EVOLUTION OF COAL TECHNOLOGY AND ITS PERSPECTIVES}

Worldwide energy and mainly electricity consumption are projected to grow at an average annual rate of $2.4 \%$ between now and 2030 (Table 1) caused by increase of population (up to 
7.5 billion) and increase of consumption (mainly of China and India). Coal offers an abundant widely spread fossil energy resource, available at a stable price from many international suppliers and it will continue to play a significant role in new generating capacity, if security and diversity of supply remains fundamental. In this paper we will point out the state of the art of coal technologies and discuss if coal is really an opportune pathway for 21 st century.

Even if coal does not represent a long term solution for the energetic problem it could be a strategic element in the mid term for the development of poor countries and for maintaining acceptable levels of welfare of others. Today the $23 \%$ of world primary energy comes from coal. About $36 \%$ of the world's electricity is produced using coal. Coal is the main fuel for electricity in USA, Germany, China, India, South Africa, Australia and much of central Europe [5-6]. Moreover 70\% of the world's steel is produced by coal. The negative perception of coal is mostly related to the dirty and dangerous mines with poor working conditions, smog and suit, old technology and to the abundant pollutants $\left(\mathrm{CO}_{2}, \mathrm{SO}_{\mathrm{x}}, \mathrm{NO}_{\mathrm{x}}\right.$, and other). But in the last years a positive perception is emerging due to the abundant supply, the cheap nature of fuel, the growing interest of industrialized country and the efforts to R\&D for the New Clean Technologies. All over the world there are today hundreds of Gigawatts (GW) of coal-fired generating capacity, mostly subcritical units with a capacity range of 100-300 MWe. The present policy is to close units of 100MWe and smaller, to modernize the 100-300 MWe units and to construct new larger units. Furthermore, environmental challenges can be addressed through technology improvements. Cleaner Fossil Fuels will remain the realistic option to provide Europe energy security, and commercial energy access. Coal-fired power plants are among the oldest power plants in operation in the world (at least on average). Although a lifetime of 30 years for a coal-fired power plant is not exceptional (more than 80 GW of plants installed in Europe are more than 30 years old). Thus in Europe, as in many countries there are both a desire and a necessity to utilize coal as an important energy resource to meet both rising electricity demand and plant retirements. Till to the beginning of the Sixties a great technological evolution of Pulverized Coal Combustion (PCC) based on thermodynamic optimization has been observed. At the end of the '50, the first supercritical cycles were developed in U.S.A. The majority of these PCC power plants had no emissions control equipments other than some particulate removal systems. Since the Sixties there has not been meaningful efficiency improvement, but growing attention to $\mathrm{SO}_{\mathrm{x}}$ and $\mathrm{NO}_{\mathrm{x}}$ emissions. Only in the Nineties a renewed interest in the Super Critical Pressurized Fuel (SCPF) technology was carried out reaching the actual standard level of 300 bar and $600{ }^{\circ} \mathrm{C}$. 
Table 2 contains data about some coal fired utility plants constructed worldwide during the second part of the $20^{\text {th }}$ century. The standard of today is represented by the parameters of Table 3 and the typical size of the plants is 700-1000 MW.

\section{WHAT MAKES COAL "UNCLEAN" AND WHAT "CLEAN COAL" TECHNOLOGIES CLAIM}

Coal is a complex chemical latticework of carbon, hydrogen, and dozens of trace elements. When combusted, some of these elements, such as sulfur, nitrogen and mercury, are converted to chemical forms that can create pollutants in the air and water. Carbon, the main constituent, combines with oxygen during combustion forms carbon dioxide $\left(\mathrm{CO}_{2}\right)$, which has been identified as a key contributor to Global Warming. Coal also contains sulphur that burns producing $\mathrm{SO}_{2}$. Moreover coal-fired stations emit tonnes of ash through their chimneys, the $80 \%$ of which is particulates smaller than 10 micrometers (PM10), arsenic, hydrochloric acid, mercury, nickel and lead. Moreover combustion produces $\mathrm{NO}_{\mathrm{x}}$.

Public awareness and legislation have led to a policy of reduction of pollutant from coal-fired power generation, with the regulations partially driven by international initiatives such as the Kyoto protocol. The local acceptance of new plants is generally based on the choice of pollutant emission limits well below the existing legislation (e.g. in USA, Japan, Italy). The Italian environmental limits are represented today by $400 / 200 / 50 \mathrm{mg} / \mathrm{nm}^{3}$ for $\mathrm{SO}_{2}, \mathrm{NO}_{\mathrm{x}}$, and Particle Matter, while the European Directive 2001/80/CE that will be operative by the next years, reduces the limits at 200/200/30 mg/nm $\mathrm{m}^{3}$ for $\mathrm{SO}_{2} \mathrm{NO}_{\mathrm{x}}$ and Particle Matter. "Clean coal technologies" are the basis for long-term acceptance of coal and is a flexible concept which can be used by all countries. Three different stages to achieve "clean coal" are available:

- I control and reduction of pollutants $\mathrm{SO}_{2}, \mathrm{NO}_{\mathrm{x}}$, mercury and $\mathrm{PM}$ (excluding $\mathrm{CO}_{2}$ ) without structural modification of the cycle

- II advanced technologies (the efficiency pathway)

- III long term vision of $\mathrm{CO}_{2}$ capture and storage

\subsection{Pollutant emission control}

There are various technologies and processes that can be utilized throughout the coal fuel cycle to mitigate negative environmental impacts . The available technologies are:

1. Removal the source of pollution (sulphur, nitrogen) from the coal before it is burnt; 
2. Avoiding the production of the pollutants during combustion (in-furnace measures);

3. Removing the pollutants from the flue gases by "end of pipe" methods prior to be emitted.

\subsubsection{NO control options}

Depending on the fuel used, the combustion conditions, the air ratio and the flame type in the burner, a considerable mass of nitrogen oxide might be produced during the combustion process. Three primary sources of $\mathrm{NO}_{\mathrm{x}}$ formation in combustion processes are documented:

- formation due to a high temperature combustion depending on the residence time of nitrogen at that temperature (Thermal $\mathrm{NO}_{\mathrm{x}}$ );

- formation of fuel bound nitrogen to $\mathrm{NO}_{\mathrm{x}}$ during combustion $\left(\right.$ Fuel $\left.\mathrm{NO}_{\mathrm{x}}\right)$;

- formation due to the reaction of atmospheric nitrogen, $\mathrm{N}_{2}$, with radicals such as $\mathrm{C}, \mathrm{CH}$, and $\mathrm{CH}_{2}$ fragments derived from fuel (Prompt $\mathrm{NO}_{\mathrm{x}}$ ).

One of the most common methods of post-treatment is the Selective Catalytic Reduction (SCR) generally used when higher $\mathrm{NO}_{\mathrm{x}}$ reduction is required. The SCR achieves reductions of about $90 \%$ when is applied by temperature from 300 to $400^{\circ} \mathrm{C}$. Many other technologies are available; Table 4 summarizes the various options with their limits level. [7]. The paper [8] reviews the history of NO, control implementation, with an emphasis on the role that research has played on NO, control technology, development and implementation.

\subsection{2 $\mathrm{SO}_{x}$ reduction}

Coal contains significant amounts of sulfur. When burned, about $95 \%$ or even more of the sulfur is converted to sulfur dioxide $\left(\mathrm{SO}_{2}\right) . \mathrm{SO}_{2}$ can be removed from flue gases by a variety of methods (Table 5). $\mathrm{SO}_{2}$ is an acid gas and thus the typical sorbent used to remove the $\mathrm{SO}_{2}$ from the flue gases are alkaline. Post-combustion removal, including Wet and Dry Flue Gas Desulphurization (FGD and DFGD) or spray dry-scrubbing. FGD is the current state-of-the art technology used for removing $\mathrm{SO}_{2}$ from the exhaust gases in power plants. Many "conventional" PF stations (with Low $\mathrm{NO}_{\mathrm{x}}$ burners) have FGD fitted. For a typical coal-fired power station, FGD will remove $95 \%$ or more of the $\mathrm{SO}_{2}$ in the flue gases. Wet Flue Gas Desulphurization (FGD) utilizes a variety of slurry of sorbent materials to scrub the gases in order to accomplish $\mathrm{SO}_{2}$ removal efficiencies approaching $99 \%$ (reduction in the treated flue gas). These reagents include limestone $\left(\mathrm{CaCO}_{3}\right)$, lime $(\mathrm{CaO})$, caustic soda $(\mathrm{NaOH})$ and related variants to absorb and neutralize the $\mathrm{SO}_{2}$ in the flue gas. Table 5 provides the main 
control technologies with their potential reduction [7]. A book, [9] provides a collection of papers concerning emissions reduction of $\mathrm{SO}_{\mathrm{x}}$ and $\mathrm{NO}_{\mathrm{x}}$.

\subsubsection{PM controls (Mainly post-combustion methods)}

PM composition and emission levels are a complex function of coal properties, boiler firing configuration, operation and pollution control equipments. In the combustion of solid fuel dust and ashes, that are included in the exhaust gases as small particulate, are produced. PM control is mainly possible with post-combustion methods, like electrofilters, cyclones and ceramic filter with quite good results (Table 6). The problem of PM emission of coal plants is discussed in several scientific papers like [10] and [11].

\subsubsection{Mercury control}

Mercury control R\&D includes sorbents and oxidizing agents that can change gaseous mercury into solids, which can be captured. The oxidizing agents work inside wet flue gas scrubbers to capture mercury in the sulfate by-product. $\mathrm{Hg}$ capture with existing controls depends on coal and technology type, being more difficult to control Hg from low rank coalfired boilers. Sorbent injection is an emerging $\mathrm{Hg}$ control technology. The paper [12] presents an overview of research related to mercury control technology for coal-fired power plants and identifies areas requiring additional research and development.

\subsubsection{The new concept of coal plant}

Each component in the flue gas cleaning section is designed to remove a specific pollutant but, besides this, can also have a beneficial effect on other macro and micro pollutants, substantially increasing the global abatement performance. According to literature, good results can be obtained using the various pollutant control technology [13]. But a different vision of coal plant as energy system is emerging. Coal-fired power plants as the one described in Fig. 1 generate significant quantities of solid byproducts such as fly ash or gypsum. The call for more stringent emission reductions through multi-pollutant regulations has the potential to alter the future use of coal by-products and may make certain auxiliary product (limestone) or by-products (gypsum) a problem that need to be considered.

\subsection{Advanced technological options for coal conversion}

Energetic performances and pollutant emissions from electric power generating plant can be further reduced by the improvement of the thermodynamic cycle of power generation. New 
requirements to limit environmental emissions impose a shift from the steam cycle to the gas cycle based plant. Technologies of interest with the possible variant are summarized in Fig. 2 . Those are mainly

- Advanced Ultra Supercritical Pressurized fuel combustion plants (USC)

- Fluidized Bed Combustion (FBC) incorporating also advanced supercritical steam cycle

- Integrated Gasifier Combined Cycle (IGCC)

- Externally Fired Combustion Combined Cycle (EFCC)

\subsubsection{Ultra Super Critical Plants (USC)}

The use of Ultra Super Critical (USC) parameters for steam represents on of the sure evolution of pulverized coal fired power plants. [14]. In addition to the advance in the steam conditions, it incorporates several clean air technologies: new design of burners, new scheme of combustion in the boiler furnace, new design of steam super heaters and gas cleaning systems. USC technology is well known; according to [15] over 550 super critical PCC are available all over the world for an amount of $300 \mathrm{GW}$ (about 150 in USA, over 100 in Japan and Russia, more than 30 in Germany). With the term "ultra-super-critical" the overcoming of the limit conditions for the steam at the level of $300 \mathrm{bar} / 600{ }^{\circ} \mathrm{C} / 600{ }^{\circ} \mathrm{C}$, to reach more advanced operating parameters towards to the increase of pressure and turbine inlet temperature is evidenced. The currently available power plants based on supercritical steam boiler at $600{ }^{\circ} \mathrm{C}$ permit to reach efficiencies of $45-47 \%$. The limits of this technology are today under discussion. The analysis carried out by some researchers and producers indicated an agreement about the long-term objective of reaching a steam pressure level of 350 bar and maximum steam temperature of $700{ }^{\circ} \mathrm{C}$ with the use of advanced material (AD700 USC plants). The perspective is to achieve net efficiencies of $50 \%$ and more.

\subsubsection{Pressurized Fluidized Bed (PFBC)}

Fluidized bed combustion represents a straightforward evolution of the circulating fluidised bed combustion, which has gained great attention from the Seventies [16]. Fluidization means that the solid coal particles are supported and mixed with air which is injected into the system. Burning occurs at $760-930^{\circ} \mathrm{C}$, well below the $1370^{\circ} \mathrm{C}$ needed to generate nitrogen oxide pollutants. It permits basically the possibility of a strong reduction of $\mathrm{SO}_{2}$ and $\mathrm{NO}_{\mathrm{x}}$ emissions with respect to pulverized coal power plants. $\mathrm{SO}_{2}$ is captured by limestone injection, $\mathrm{CO}_{2}$ is controlled by sorbents. The resulting flue gas can be used in turbine. 
Fluidised bed combustion technologies are of various types. They include atmospheric pressure Fluidised Bed Combustion (FBC), Circulating (CFBC) or Pressurized Fluidised Bed Combustion (PFBC) and Pressurised Circulating Fluidised Bed Combustion (P-CFBC).

From the thermodynamic point of view, the main benefit obtained from pressurized fluidised bed consists on the possibility of increasing the plant efficiency, coupling a Rankine cycle with a gas turbine. The controlled combustion permits a flexibility in the use of fuel (i.e. the use of a low quality coal). The resulting process is a hybrid cycle, but the steam turbine generates the high percentage of the power (until the $80 \%$ ). The currently available efficiency is lower than $40 \%$ and many problems during operation have been evidenced in the various experimental facilities.

\subsubsection{Integrated Gasifier Combined Cycle (IGCC)}

Since twenty years ago Integrated Gasifier Combined Cycles (IGCC) are considered the future of coal combustion. IGCC first turns the coal into gas (mostly $\mathrm{CO}$ and $\mathrm{H}_{2}$ ), then sulphur, ash, mercury and other pollutants are removed and finally the clean gas is fed to the Central Power (Fig. 3). IGCC allows coal to benefit from gas turbine advances [17] and permits simpler $\mathrm{CO}_{2}$ control if required [18]. Multiple Gasification process technologies are available, like as [19]:

-Entrained flow (Shell, GE (Texaco), Conoco-Phillips (Dow/Destec))

-Fixed bed (BGL, Lurgi, EPIC)

-Fluidized bed (Southern Co- Staunton, KRW)

These processes allow a large variety of plant configurations [20]. Plants are operating successfully in Spain, the Netherlands and USA. Among them a 253 MWe IGCC power plant of Buggenum (the Netherlands), a 252 MWe IGCC of Wabash River (Indiana-USA), a 250 MWe IGCC of Polk County (Florida-USA) and a 318 MWe IGCC of Puertollano (Spain) are of particular interest because based on coal as primary fuel. Efficiency is in the range between 35 and $42 \%$. The specific cost of commercial version of similar plants is estimated to be about the 40-60\% higher than a conventional PCC plant. IGCC is basically the cleanest coal technology with inherently lower $\mathrm{SO}_{\mathrm{x}}, \mathrm{NO}_{\mathrm{x}}$, and $\mathrm{PM}$, lowest collateral solid wastes and wastewater, potential for lowest cost removal of mercury and cheapest route to $\mathrm{CO}_{2}$ separation. Notwithstanding some successful experiments, the low number of operating plants showed a lot of problems, mostly concerning the availability. In the meantime the renewed 
interest in the conventional PCC power plants made quite less attractive investments on IGCC. But IGCC becomes a solution of interest for petrolchemical industry (Tab. 7). More than 120 plants were in operation in 2004. The facilities produce mostly chemicals (37\%), gas $(36 \%)$ or power $(19 \%)$. In terms of feedstock, some of them are solid feedstock based (coal and petroleum coke), others are refinery high sulfur heavy oil based. Only a small number of them is based on coal.

For this reason IGCC technology holds great promise for the future due to the flexible feedstock, process options and products and opens new markets for coal (syn-fuels, chemicals, fertilizers). It also provides the only feasible bridge from coal to hydrogen (directly converts coal to hydrogen). But in the meantime new barriers are growing to deployment of IGCC. The first is the power industry culture. While a conventional coal plant places a chemical plant at the back end, attempting to capture pollutants after combustion with much dilution, IGCC places the chemical plant in the front end of the power plant (Fig. 3 ) and it is basically a chemical plant. Power companies do not like chemical units, moreover there are a lot of technical and financial risks and finally companies don't understand why they should build IGCC when it is possible to get a permit for a conventional coal plant.

\section{THE FUTURE CHALLANGES OF CLEAN COAL TECHNOLOGIES}

$\mathrm{CO}_{2}, \mathrm{SO}_{2}$ and $\mathrm{NO}_{\mathrm{x}}$ have been mentioned above as some of the things that made coal "unclean". The good possibility of reducing the level of $\mathrm{NO}_{\mathrm{x}}$ and $\mathrm{SO}_{\mathrm{x}}$ are summarized in Tables 4, 5 and 8. Let's consider now the problem of $\mathrm{CO}_{2}$. It is well known that recent Pulverized Coal Combustion (PCC) plants are characterized by a level of $\mathrm{CO}_{2}$ emission in the range between 850 and $900 \mathrm{~g} / \mathrm{kWh}$. The level of $750 \mathrm{~g} / \mathrm{kWh}$ can be reached both by means USC plants and IGCC plants. It is really difficult that the barrier of $750 \mathrm{~g} / \mathrm{kWh}$ can be broken without any mitigation strategy. Coal (C) emits at least the double of $\mathrm{CH}_{4}$. Emission factor from coal $(\mathrm{EFc})$ can be calculated by

$$
\mathrm{EF}_{\mathrm{C}}=\frac{\mathrm{CR} \cdot \mathrm{CC} \cdot \mathrm{CE} \cdot 44}{\mathrm{HV} \cdot 12}
$$

where HV is the Heating Value of the fuel (12-32 MJ/kg), CC is the Carbon Content of coal (60-90\%), CE is the Combustion Efficiency (0.9-0.95) and CR is an opportune conversion rate $(0.2778$ in case of MW and KWh). In usual conditions EFc is approximately in the range 
between 0.3-0.4 $\mathrm{kgCO}_{2} / \mathrm{kWh}_{\mathrm{th}}$. Considering the actually available efficiency values $(0.35-$ 0.45 ) it gives a level of emissions energy produced of $0.750-1 \mathrm{kgCO}_{2} / \mathrm{kWh}_{\mathrm{el}}$.

The advanced technologies for coal conversion like USC and IGCC can contribute to the $\mathrm{CO}_{2}$ emission mitigation mostly due to the efficiency increase (USC technology) and to the different plant architecture (IGCC). Fig. 4 summarizes the range of specific $\mathrm{CO}_{2}$ emission available with the various coal technologies in comparison with the reference level represented by $\mathrm{CO}_{2}$ emission of Natural Gas Combined Cycle (NGCC) plants.

\section{1 $\mathrm{CO}_{2}$ emissions control and the mitigation technologies}

To maintain the position of coal in the global energy mix in a $\mathrm{CO}_{2}$-constrained world, the crucial question about the future of coal technologies remains the perspective of a considerable reduction of the $\mathrm{CO}_{2}$ emissions from its utilization. To reduce $\mathrm{CO}_{2}$ emissions from coal-fired power generation, two strategies can be perceived: improving efficiency or resorting to capture and storage of $\mathrm{CO}_{2}$ from conventional plants. Three main strategies are analyzed in order to mitigate the $\mathrm{CO}_{2}$ emissions produced by coal:

- Post-Combustion (removal of $\mathrm{CO}_{2}$ from combustion flue gases).

- Oxy-Fuel Combustion (combustion with pure $\mathrm{O}_{2}$ and Recycled Flue Gas)

- Pre-Combustion (separation of $\mathrm{CO}_{2}$ from the fossil fuel)

Even if the second and the third are promising strategies, the control of $\mathrm{CO}_{2}$ emissions from coal fired power plants is possible through end-of-pipe (post-combustion) processes.

The most suitable technology appears to be the chemical absorption, which is based on the $\mathrm{CO}_{2}$ concentration and its partial pressure at the capture point. This method has been widely analyzed in literature, being the most applied one. Under an energetic point of view this technology requires a great amount of energy to achieve the $\mathrm{CO}_{2}$ capture, with a great impact on the thermodynamic performance of the plant that seriously decreases power generation efficiency (Fig. 5). The $\mathrm{CO}_{2}$ capture systems demand a significant amount of energy for their processes requiring more fuel per $\mathrm{kWh}$ generated, reducing net plant efficiency, increasing other environmental pollutants (ammonia, limestone). According to the currently available literature, a reduction of efficiency estimated in 7-8 point percentage (from $40 \%$ to $32 \%$ ) can be estimated. [4]. Economically talking, the development of this technology without much modification to the plants can be a transitory short-term solution for existing plants. The estimated increase of costs is of the order of $35-40 \%$ (from $1100-1200 € / \mathrm{kW}$ to about 1600 - 
$1700 € / \mathrm{kW}$ for conventional PCC plant with $\mathrm{CO}_{2}$ capture). However several key questions remain, including cost and performance of integrated power and capture technologies about how sustainable could be $\mathrm{CO}_{2}$ capture as a mitigation strategy.

In spite of the important research efforts and the great emphasis associated to the development of pollutant emission control, the concept of $\mathrm{CO} 2$ capture in power generation is still in a developing phase. The different options offer an enormous engineering challenge but do not seem to be valid solutions for existing power plants.

\subsection{Research and development lines in the field of "Clean Coal Technologies"}

Under the urgent need of advanced technologies for electricity generation using coal as fuel, projects related to clean coal technologies for power generation are undertaken worldwide, particularly in the United States and in Europe. Primary focus of these efforts is to develop innovative concepts for pollutant control. The projects concern new and advanced technologies for pollutant control $\left(\mathrm{SO}_{\mathrm{x}}, \mathrm{NO}_{\mathrm{x}}, \mathrm{PM}\right.$, etc.) including more economic and ecocompatible than the actually available, that can be retrofitted to existing baseload coalfired power generating capacity. Major efforts include low- $\mathrm{NO}_{\mathrm{x}}$ combustion, mercury control, fine particulate control, by-product utilization, water management, analysis on mercury formation during combustion and during the subsequent treatments. Other research lines concerns new materials and advanced diagnostics for USC plants, IGCC Plants with $\mathrm{CO}_{2}$ capture and separation, "zero liquid discharge" plants. The promising EFCC technology is nowadays only at evaluation of proof concepts but it seems the only one strategy for promoting the development of low size plants (10-50 MW) based on coal as primary fuel.

\section{CONCLUSIONS}

Over the past decade, the role of coal as an energy source for the future has gained renewed interest and it is, therefore, likely that coal will remain in an important position among the primary resources. Concerning the emission control strategies it is possible to observe good success in controlling $\mathrm{PM}, \mathrm{NO}_{\mathrm{x}}$ and $\mathrm{SO}_{\mathrm{x}}$ emissions. Advanced, low-cost emissions control systems have been successfully demonstrated and employed in several plants, but difficulties for the maintenance of standards during operating life of the plant is observed. Moreover the high sensitivity to the type of coal used and the problems with auxiliary material (ammonia, urea, limestone, gypsum) are well known.

Regarding the advanced technologies, it is clear that the clean coal technologies, which are likely to make serious contributions to energy sector in the next years are on the one hand 
supercritical pulverised coal firing and on the other hand integrated gasification combined cycles. A superiority of USC solution in a mid-term scenario can be evidenced. From a longterm perspective, the development of IGCC solutions appears interesting, due to the inherently cleaner process because coal is not combusted and pollutants can be removed with greater efficiency. About $\mathrm{CO}_{2}$ capture and storage only early research work and promising strategies are available but uncertainty about perspectives is apparent. The application of $\mathrm{CO} 2$ capture technologies to the existing plants appears to be a quite critical task but it appears really interesting the development of power plants in which the removal systems be integrated into the process.

\section{References}

[1] World Coal Institute. The coal resource: a comprehensive oveview of coal. London, UK: World Coal Institute 2005. See also http://www.worldcoal.org/assets_cm/files/PDF/ thecoalresource.pdf

[2] Beer JM. Combustion technology developments in power generation in response to environmental challenges, Progress in Energy and Combustion Science 2000, 26: 301327.

[3] Longwell JP, Rubint ES, Wilson J. Coal: energy for the future, Prog. Energy Combust. Science 1995; 21: 269-360.

[4] Beér JM. High efficiency electric power generation: The environmental role. Progress in Energy and Combustion Science 2007; 33: 107-134.

[5] International Energy Agency. Key World Energy Statistics 2007. International Energy Agency (IEA) Paris Cedex 15, France, 2007. See also http://www.iea.org/textbase/nppdf/free/2007/key_stats_2007.pdf.

[6] BP. BP Statistical Review of World Energy June 2008. BP Statistical Review of World Energy. London, UK. See also http://www.bp.com/productlanding.do? categoryId=6929\&contentId=7044622.

[7] U.S. Environmental Protection Agency, AP 42, Fifth Edition, Volume I, Chapter 1: $\begin{array}{lllll}\text { External } & \text { Combustion } & \text { Sources } & \text { See } & \text { also }\end{array}$ http://www.epa.gov/ttn/chief/ap42/ch01/index.html.

[8] Muzio LJ, Quartucy GC. Implementing $\mathrm{NO}_{\mathrm{x}}$ control: research to application. Progress in Energy and Combustion Science . 1997; 23: 233-266. 
[9] Tomita A. (Ed.). Emissions reduction: NOx/SOx suppression. A collection of papers from the journals Fuel, Fuel Processing Technology and Progress in Energy and Combustion Science 1999-2001. Elsevier, 2001.

[10] Meij R, te Winkel H. The emissions and environmental impact of PM10 and trace elements from a modern coal-fired power plant equipped with ESP and wet FGD. Fuel Processing Technology 2004; 85: 641-656

[11] Tucker WG. An overview of $\mathrm{PM}_{2.5}$ sources and control strategies. Fuel Processing Technology 2000; 65-66: 379 -392

[12] Pavlish JH, Sondreal EA., Mann MD, Olson ES, Galbreath. KC, Laudal DL, Benson SA. Status review of mercury control options for coal-fired power plants. Fuel Processing Technology 2003; 82: $89-165$.

[13] Arrighi L, Bracaloni N. From old oil to clean coal: transforming Torrevaldaliga Nord in Modern Power Systems 2003; 23 (11): 25-28.

[14] Bugge, J, Kjaer S. High efficiency coal fired power plants development and perspectives, Proceedings of ECOS 2003 Conference, Copenhagen, pp. 1349-1354, 2003.

[15] Luby P. Supercritical Systems. Recent trends in a market sector that has seen dramatic changes in the last ten years, Modern Power Systems 2003; 23 (8): 27-34.

[16] Koornneef J, Junginger M, Faaij A. Development of fluidized bed combustion - An overview of trends, performance and cost. Progress in Energy and Combustion Science, 2007; 33: 19-55.

[17] Lozza G, Chiesa P, De Vita L. Combined-cycle power stations using clean-coal technologies: thermodynamic analysis of full gasification versus fluidized bed combustion with partial gasification, Transactions of the ASME, Journal of Engineering for Gas Turbines and Power 1996; 118: 737-748.

[18] Pruschek R, Oeljeklaus G, Haupt G, Zimmermann G, Jansen D, Ribberink JS. The role of IGCC in $\mathrm{CO}_{2}$ abatement, Energy Conversion and Management 1997; 38: 153-158.

[19] Zheng L, Furinsky E. Comparison of Shell, Texaco, BGL and KRW gasifiers as part of IGCC plant computer simulations, Energy Conversion and Management 2005, 46: 17671779.

[20] Hasegawa T, Sato M., Nakata T. A Study of Combustion Characteristics of Gasified coal Fuel, ASME Journal of Engineering for Gas Turbines and Power 2001; 123: 22-32. 
Tables and captions

\begin{tabular}{ccccccc}
\hline Year & $\begin{array}{c}\text { Electric energy } \\
\text { production [Twh] }\end{array}$ & $\begin{array}{c}\text { Coal } \\
(\boldsymbol{\%})\end{array}$ & $\begin{array}{c}\text { Natural } \\
\text { Gas }(\boldsymbol{\%})\end{array}$ & $\begin{array}{c}\text { Oil } \\
(\boldsymbol{\%})\end{array}$ & $\begin{array}{c}\text { Nuclear } \\
(\boldsymbol{\%})\end{array}$ & $\begin{array}{c}\text { Renewable } \\
(\boldsymbol{\%})\end{array}$ \\
\hline 2005 & 18235 & 40.3 & 19.7 & 6.6 & 15.2 & 18.2 \\
2030 & 26600 & 32 & 27 & 9 & 12 & 20 \\
\hline
\end{tabular}

Table 1. Electric energy production by sources (the data of 2005 are from [5])

\begin{tabular}{|c|c|c|}
\hline Central name & State and year of installation & Steam conditions \\
\hline Eddystone I & USA $\quad 50$ & 345 bar, $\quad 649^{\circ} \mathrm{C} / 566^{\circ} \mathrm{C} / 566^{\circ} \mathrm{C}$ \\
\hline Kashira & Russia & 306 bar, $\quad 650^{\circ} \mathrm{C} / 565^{\circ} \mathrm{C}$ \\
\hline Typical USA coal plants & USA & $566^{\circ} \mathrm{C} / 566^{\circ} \mathrm{C}$ \\
\hline Typical Italian PCC plant & Italy & $250 \mathrm{bar}, \quad 540^{\circ} \mathrm{C}, 540^{\circ} \mathrm{C}$ \\
\hline Kawagoe & Japan & $311 \mathrm{bar}, \quad 566^{\circ} \mathrm{C} / 566^{\circ} \mathrm{C} / 566^{\circ} \mathrm{C}$ \\
\hline Frimmesdorf & Germany & 250 bar, $\quad 580{ }^{\circ} \mathrm{C} / 600^{\circ} \mathrm{C}$ \\
\hline Averdore 2 & Denmark & $580^{\circ} \mathrm{C} / 600^{\circ} \mathrm{C}$ \\
\hline Torrevaldaliga Nord & Italy & $600^{\circ} \mathrm{C} / 610^{\circ} \mathrm{C}$ \\
\hline
\end{tabular}

Table 2. The thermodynamic evolution of coal plants

\begin{tabular}{lc}
\hline \multicolumn{1}{c}{ Indicator } & Range \\
\hline Efficiency & $36-40 \%$ \\
Size $(\mathrm{MW})$ & $300-1000$ \\
$\mathrm{CO}_{2}$ Emission $(\mathrm{kg} / \mathrm{MWh})$ & $850-1000$ \\
$\mathrm{NO}_{\mathrm{X}}$ Emission $(\mathrm{kg} / \mathrm{MWh})$ & $0.5-1.5$ \\
$\mathrm{SO}_{2}$ Emission $(\mathrm{kg} / \mathrm{MWh})$ & $0.5-0.7$ \\
$\mathrm{PM}$ Emission $(\mathrm{kg} / \mathrm{MWh})$ & 0.1 \\
Capital cost $(\mathrm{US} \$ / \mathrm{KW})$ & $1100-1200$ \\
\hline
\end{tabular}

Table 3. Reference data for an installed coal plant: sub-critical units and conventional sulfur control 


\begin{tabular}{lc}
\hline \multicolumn{1}{c}{ Control Technique } & NO reduction potential (\%) \\
\hline Overfire air (OFA) & $20-30$ \\
Low NO ${ }_{x}$ Burners (LNB) & $35-55$ \\
LNB + OFA & $40-60$ \\
Reburn & $50-60$ \\
SNCR (Selective non Catalytic Reduction) & $30-60$ \\
SCR (Selective Catalytic Reduction) & $75-85$ \\
LNB with SCR & $50-80$ \\
LNB with OFA and SCR & $85-95$ \\
\hline
\end{tabular}

Table 4. Potential Reduction of $\mathrm{NO}_{\mathrm{x}}$ control technologies [7]

\section{Control Technique}

Pre combustion removal: Physical cleaning

Chemical and biological cleaning

Combustion configuration: Fluid Bed

Post-combustion removal: Wet Flue Gas Desulfurization (FGD)

In situ sulfur capture: Dry Sorbent Injection (DSI)
SO reduction potential $(\%)$

(30-50\% removal inorganic sulfur)

(90\% removal organic sulfur)

Table 5. Potential Reduction of $\mathrm{SO}_{\mathrm{x}}$ control technologies [7]

\section{Control Technique}

Electrostatic precipitator (ESP)

Filters

Wet scrubber

Cyclone

\section{Reduction potential $(\%)$}

$99 \%$ (for $0.1<\mathrm{d}(\mathrm{mm})<10$ )

As high as $99.9 \%$

95-99\%

$90-95 \%(\mathrm{~d}(\mathrm{~mm})>10)$

Table 6. Potential Reduction of PM control technologies [7] 


\begin{tabular}{lcclc}
\hline \multicolumn{1}{c}{ Project - Location } & Start-Up & MW & \multicolumn{1}{c}{ Products - Feedstock } & Availability (h/y) \\
\hline Cool Water & 1984 & 120 & Power - syngas / Coal & $6000-8000$ \\
Bugghenum - The Netherlands & 1994 & 250 & Power / Coal & $<6000$ \\
Wabash - USA & 1995 & 260 & Repower / Coal, Pet Coke & $<8000$ \\
Tampa Elec. Company - USA & 1996 & 250 & Power / Coal, Petroleum Coke & $>5000$ \\
Puertollano - Spain & 1998 & 320 & Power / Coal, Coke & $<1000$ \\
Pinon Pine - USA & 1998 & 107 & Power / Coal & \\
Schwarze Pumpe - Germany & 1996 & 40 & Power and Methanol / Lignite & $>8000$ \\
Shell Pernis - Netherlands & 1997 & 120 & Cogen and H / Visbreaker Tar & \\
ISAB: ERG/Mission - Italy & 2000 & 510 & Power / Asphalt & \\
Sarlux: Saras - Italy & 2001 & 545 & Power, Steam, H / Visbreaker Tar & \\
Exxon Chemical - Singapore & 2001 & 160 & Cogeneration / Ethylene Tar & \\
API Energia - Italy & 2001 & 280 & Power and Steam / Visbreaker Tar & \\
Motiva LLC - Delaware, USA & 2002 & 160 & Repower / Pet Coke & \\
Nippon Refining - Japan & 2003 & 342 & Power / Asphalt & \\
\hline
\end{tabular}

Table 7. The experience on the IGCC plants

\begin{tabular}{lcccccc}
\hline & PF & PF+FGD & SCPF & CFBC & IGCC & NGCC \\
\hline $\mathrm{SO}_{\mathbf{X}}\left(\mathrm{mg} / \mathrm{m}^{3}\right)$ & 2250 & 200 & 150 & 150 & 25 & 0 \\
$\mathrm{NO}_{\mathrm{X}}\left(\mathrm{mg} / \mathrm{m}^{3}\right)$ & 650 & 200 & 150 & 220 & 45 & 45 \\
\hline
\end{tabular}

Table 8. Emission level of $\mathrm{NO}_{\mathrm{x}}$ and $\mathrm{SO}_{\mathrm{x}}$ for the various advanced coal plants 


\section{Figure captions}

Fig. 1. A schematic view of a classic PCC power plant with end-of-pipe emission control

Fig. 2. Advanced technologies for coal conversion

Fig. 3. Integrated Gasifier Combined Cycle: schematic

Fig. 4. Emission level of $\mathrm{CO}_{2}$ for the various technologies coal plants

Fig. 5. Comparison of $\mathrm{CO}_{2}$ emissions for plants with and without capture $(\mathrm{kg} / \mathrm{kWh})$ 
Figures and captions

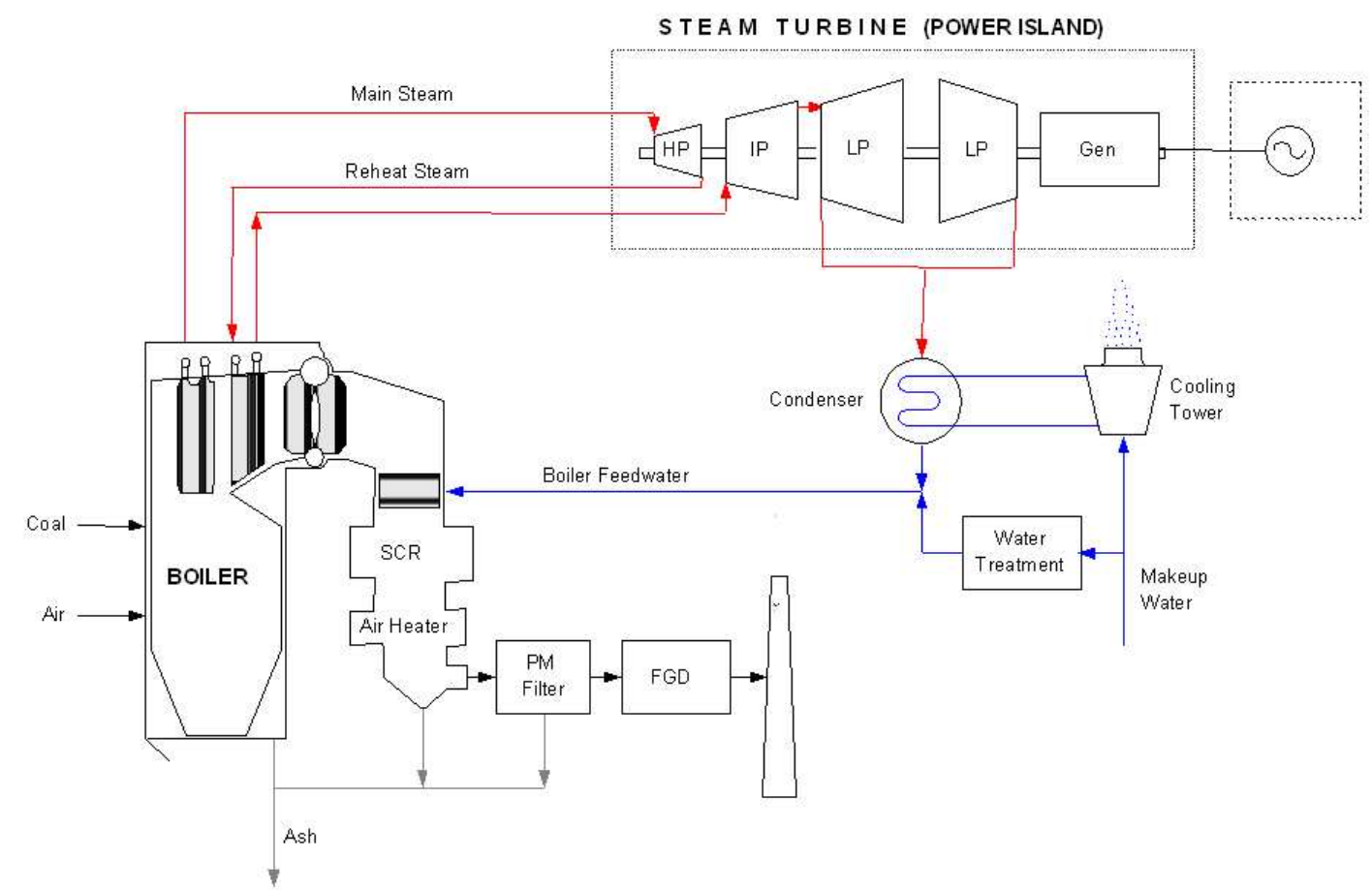

Fig. 1. A schematic view of a classic PCC power plant with end-of-pipe emission control 


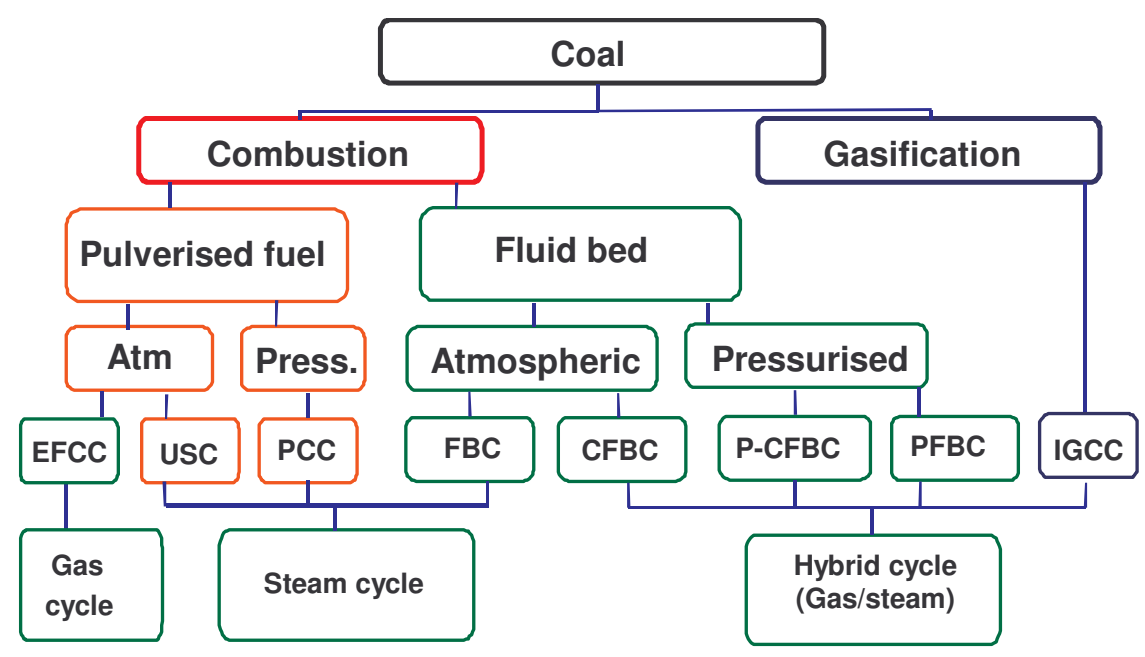

Fig. 2. Advanced technologies for coal conversion 


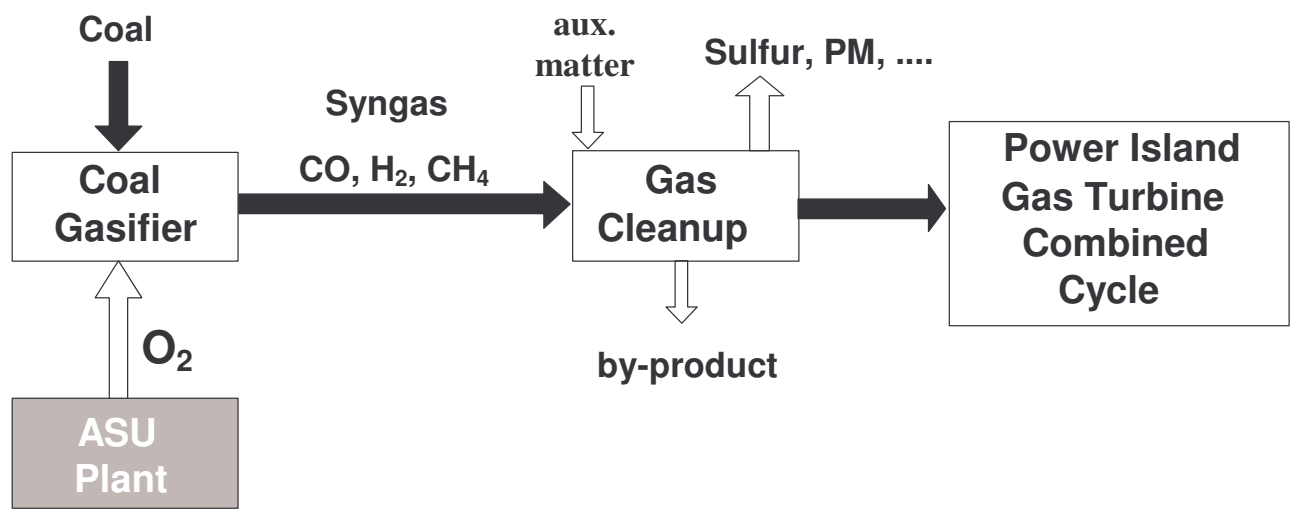

Fig. 3. Integrated Gasifier Combined Cycle: schematic 


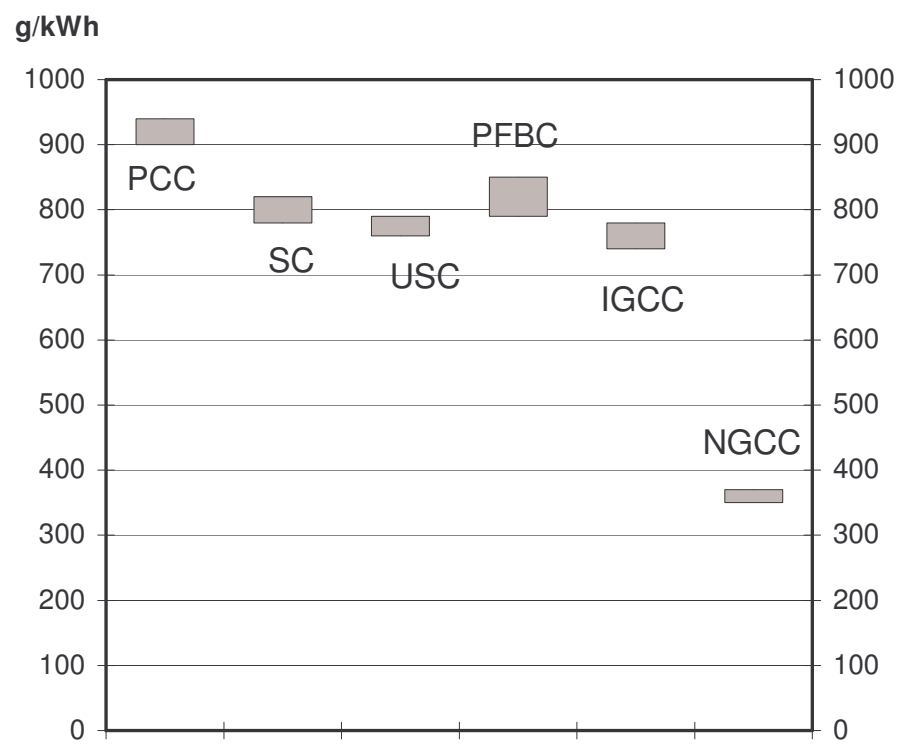

Fig. 4. Emission level of $\mathrm{CO}_{2}$ for the various technologies coal plants 

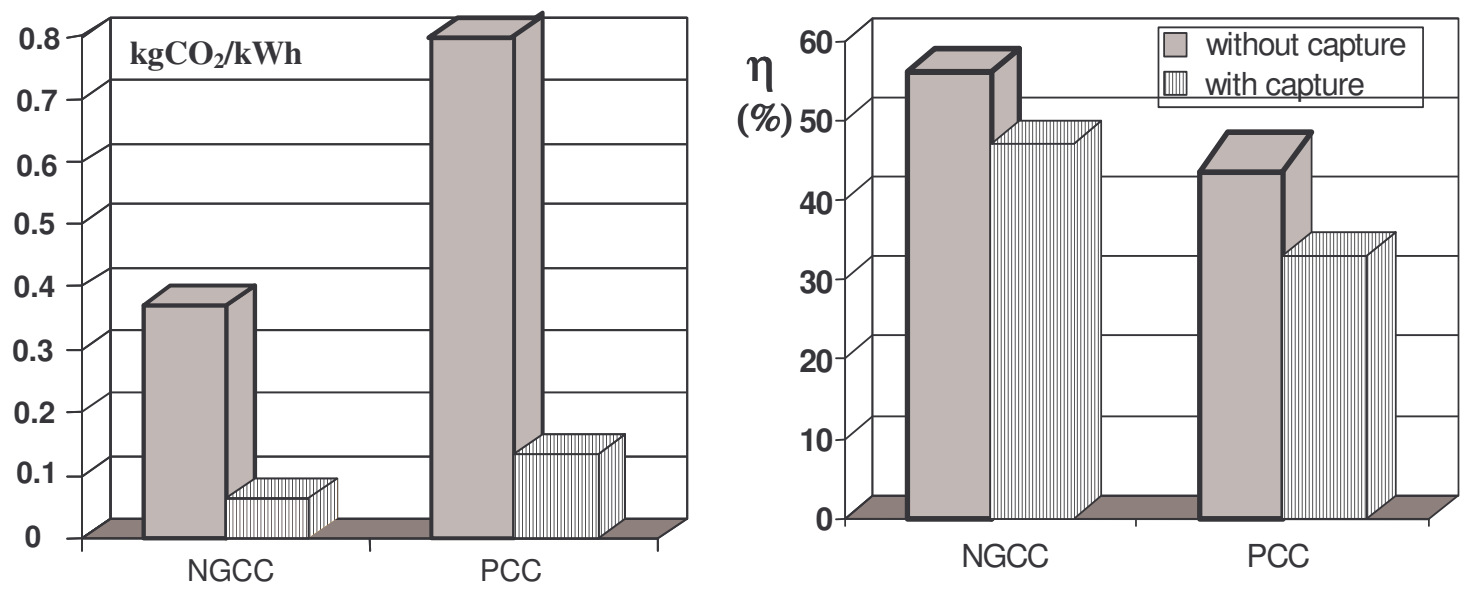

Fig. 5. Comparison of $\mathrm{CO}_{2}$ emissions for plants with and without capture $(\mathrm{kg} / \mathrm{kWh})$ 